\title{
AXIOLOGICAL ASPECTS IN THE TALE MEDENATA PITA BY KONSTANTIN KONSTANTINOV
}

\author{
ELITSA GEORGIEVA \\ Uniwersytet im. Angela Kancheva w Ruse \\ MiRA DUSHKOVA \\ Uniwersytet im. Angela Kancheva w Ruse
}

\begin{abstract}
AXIOLOGICAL ASPECTS IN THE TALE MEDENATA PITA BY KONSTANTIN KONSTANTINOV. The paper presents a linguo-cultural analysis of the tale Medenata Pita (The Honey Bread) by the Bulgarian writer Konstantin Konstantinov. The authors try to build a complex methodological apparatus for studying readers' perceptions regarding the axiological aspects of the text. The study starts with the analysis of surveys carried out among undergraduate students of Bulgarian Language and History on the axiological components of the text. Then, an analytical linguistic model is built to explain the obtained results. The conceptual metaphor Life is a journey created by Lakoff and Johnson (1980) and Lakoff and Turner (1989) serves as a theoretical underpinning; its structure is compared to the plot of the tale. The model is enriched with the interpretation of words and images typical of the traditional Bulgarian culture (bread, destiny / fate, fortune tellers, luck). In the course of the study, close connection is established between the students' answers, the linguo-cultural analytical apparatus and Konstantin Konstantinov's text.
\end{abstract}

Keywords: Konstantin Konstantinov, Medenata Pita, linguo-cultural analysis, content analysis, linguistic model, axiological approach, cognitive metaphor theory, bread, fate, fortune tellers, luck

\section{INTRODUCTION}

The linguo-cultural analysis of literary fairy lies at the boundary between linguistic and literary analytical practices. The approaches to analyze the explication of the meanings of a text are numerous. Some of the linguistically oriented theories view the narrative through the communicative and representational functions of language, emphasizing the role of 
a narrative text as a communicative act. For example, the rhetorical approaches look at the narrative as a communicative act that consists of a sender, a message and a receiver (Cf. Booth 1961; Phelan 2007). Translated into the language of a fairy tale, these could mean a teller, a reader / listener and a story. Each of the three elements may be the focus of analysis, as could be the relationship between them. The purpose of this paper is to reveal some possible mechanisms through which a given narrative text affects the readers, allowing them to deconstruct some axiological and value-laden meanings. Our interest lies in a more cognitively-oriented approach to studying the reception of a story with an emphasis on the values encoded in a text.

To this purpose, we try to build a complex methodological apparatus for studying readers' perception and meaning construal of a text in general and the interpretation of the axiological aspects of a text, in particular. The object of our analysis is Konstantin Konstantinov's tale Medenata Pita (The Honey Bread). Starting from a survey with undergraduate students in the humanities, we aim to build an analytical linguistic model. The conceptual metaphor Life is a journey as examined by Lakoff \& Johnson (1980) and Lakoff \& Turner (1989) serves as a theoretical underpinning; we compare its structure to the plot of the tale. The model is enriched with the interpretation of words and images from the text which are typical for the traditional Bulgarian culture (bread, destiny / fate, fortune tellers, luck). In the course of our work, we seek to establish a close connection between the students' answers, the linguo-cultural analytical apparatus and Konstantin Konstantinov's text.

\section{ON THE WRITER AND HIS TALE}

Medenata pita, the text under scrutiny, is an author's tale; however, it is also rich in realia from Bulgarian folklore, e.g. the image of the fortune teller (orisnitsa, орисница), the bread loaf (medenata pita, медената пuтa) made with honey as part of ritual practices, the importance of bread in traditional Bulgarian society. So far, the tale has not been a subject of linguo-cultural analysis, which provoked us to interpret it from this point of view and to look at the axological meanings in it that are typical for the Bulgarian national culture. At the same time the analysis allowed us to seek for the artistic representation of the value-laden elements in the author's tale.

The author of the tale, Konstantin Konstantinov (1890-1970), is a Bulgarian writer, essayist, memoirist and a notable translator from Russian and French. In the 1920 and 1940 s he published five collections of short stories, several collections of travel books and essays, two novels, one of which, Sartseto $v$ kartonenata kutiya (The Heart in the Cardboard Box, 1933), was co-authored by Svetoslav Minkov. Between 1959 and 1966 his memoirs Pat prez godinite (Road Through the Years) were published (Dushkova 2012: 270-285). 
Influenced by Ran Bosilek', a well-known Bulgarian author writing for children, editor of Detska Radost ${ }^{2}$ magazine, since the 1920s Konstantinov began publishing tales, stories and short stories for children: Prikazi za teb (1924), Prikazki za shturcheto (1927), Bosa Komanda (1929), Otbor Yunachi (1933), Priklyucheniyata na kotaraka Mur-Mur, Eho-o-o (1938), Zlatna kashtichka (1947), Kogato detsata zaspyat (1962), Medenata pita (1965). His children's books have been republished repeatedly and separate texts are included in reading books, textbooks and teaching aids used in the Bulgarian school curriculum at the primary stages of education. They are translated into Russian, Slovenian, Serbo-Croatian, Uzbek. His tales were used as an incentive for creative activities for pupils at primary school (e.g. in the $4^{\text {th }}$ grade of Konstantin Konstantinov Secondary School, Sliven - Bulgaria, vide Gospodinova 2003).

Konstantin Konstantinov's books for children have not yet been analyzed in detail. Among the authors who work on them are Elka Konstantinova, Petar Dobrev, Petar Syarov, Ivan Simeonov, Vladimir Yanev, Ognyana Georgieva-Teneva, Alexandra Antonova, and more recently younger scholars such as Christina Andonova and Galina Dimitrova. The critics point out Konstantinov's artistic skills, his ability to create a unique artistic world where Bulgarian folklore elements play a central role; they also mention that his works excel at providing aesthetic delight to the young readers and enriching their spiritual world. The critics also mention some characteristic motives in his books: sleep, reality, toys that come to life, etc. Other important elements of literary analysis are: the figure of the narrator, the aesthetics of memory, the image of the child, the connection with Plato's world.

Konstantin Konstantinov's tale Medenata Pita resembles Bulgarian folk tales. It tells about some typical Bulgarian cultural elements: the tale focuses on the life of a poor woman and her son, a boy, who live in a humble house and make their living by hard work. The text narrates about how the mother gets sick and sends her young son to look for the loaf of honey bread (medena pita) rolled at his birth by a fortune teller (orisnitsa). The boy sets off chasing the loaf and on his way he passes through wonderful lands. In the Golden Land,

\footnotetext{
1 Ran Bosilek (1886-1958) - pseudonym of Gencho Negentsov. Ran Bosilek is one of the most popular and loved Bulgarian writers of literature for children. He wrote poems and fairy tales. He was a chairman of the Society of Children's Writers in Bulgaria. His credit for the recognition of Bulgarian literature for children and for the artistic layout of children's books is enormous. Among his most famous books are Nerodena moma (1926), Jiva Voda (1933), but his greatest popularity is due to the Patilansko Tsarstvo series. In 1932, he won the International Shoemaker Award at the Second International Book Exhibition in Brussels for his book Nerodena Moma, illustrated by Georgi Atanasov.

2 Detska Radost Magazine (1910-1947) started out as a two-week issue of illustrated fairy tales for children and adolescents (curator Hristo T. Hadzhiev). From 1923 it became a monthly magazine edited by Ran Bosilek. One of the most famous Bulgarian editions for children in the period between the two world wars. Ran Bosilek attracted some of the most talented poets and writers - Elisaveta Bagryana, Assen Raztsvetkinov, Vassil Stoyanov, Geo Milev, Dora Gabe and many others, as well as the artists Vadim Lazarkevich, Iliya Beshkov, Aleksandar Bojinov, Nikola Kozhuharov, Rayko Aleksiev, etc.
} 
people who look like big lizards and frogs, try to lure him to stay with them, but the boy resists the temptation. At the end of the world, by the infinite sea, he finds the bread loaf, but it is no longer made with honey; rather, it is made of brown flour - a hard, cracked, poorman's loaf. When the hero sees his reflection in the water, he notices he is no longer a boy but a well-built man. On the way back, he gives some bread to the blind, and the last piece he gives to a starving homeless dog lying in front of his house. Eventually, he returns home empty-handed, but his mother is healed since she does not really need the bread loaf; she has realized that her son has a heart of gold.

There are some fantastic elements in the text (the Land of the blind, the Land of the stone-silent people and the Golden Land), and they play an important part for the artistic representation of the tale's messages. However, more important elements are the story line and the plot, as well as the main character who, in the course of the tale, reaches self-actualization. Similar to realistic folktales, Konstantinov's work has a simple and clear composition. The characters are ordinary people and the setting bears resemblance to everyday life.

\section{RESEARCH METHODOLOGY AND ANALYSIS OF THE RESPONDENTS'}

\section{ANSWERS}

We assigned Konstantin Konstantinov's Medenata Pita for home reading to $\mathbf{1}^{\text {st }}$ and $\mathbf{2}^{\text {nd }}$-year students of the Bulgarian Language and History degree course at Ruse University (Ruse, Bulgaria) assuming that, as future teachers of Bulgarian language and literature, they are already competent readers, i.e. they are able to analyze and extract value-laden information in relation to important ideas in the content of the text. Besides, they are native speakers of Bulgarian and bearers of Bulgarian traditional culture with an educational background in the humanities, so they have additional resources to read codes of culture.

We asked them to answer two questions:

1. What values does the tale teach about / assert?

2. What is the message / moral of the tale?

The answers (in writing) had to be within 100 words. We aimed to elicit direct opinions on the values expressed in the text by provoking a sense of empathy and reflection on the ethical and moral values that guide the actions of the character.

We received answers from seven students. Their texts were analyzed by applying content analysis; the key lexemes and phrases associated with the tale's moral / message and values were summarized and color coded for easier processing. The obtained data is summarized in Table 1. 
Table 1

\begin{tabular}{|c|c|c|}
\hline & Values & Message \\
\hline 1. Martina & $\begin{array}{l}\text { 1. Love your neighbor. } \\
\text { 2. Love and care to one's mother. } \\
\text { 3. Kindness. } \\
\text { 4. Compassion. } \\
\text { 5. Dedication. } \\
\text { 6. The happiness and health of the loved ones } \\
\text { are more important than gold and money. }\end{array}$ & $\begin{array}{l}\text { 1. We should help people and animals in need. } \\
\text { 2. Pursue one's goals and ignore temptations } \\
\text { and distractions. } \\
\text { 3. We should be grateful for what we have. } \\
\text { A simple repast that can be shared with is } \\
\text { more important than one fit for a king. }\end{array}$ \\
\hline 2. Suna & $\begin{array}{l}\text { 1. Compassion / to be ready to help those in } \\
\text { need. } \\
\text { 2. All the good we do makes us happy - doing } \\
\text { good = happiness. }\end{array}$ & $\begin{array}{l}\text { 1. We should listen to our inner voice (the voice } \\
\text { of the heart). No one knows what their fate } \\
\text { is and what the road ahead might be so our } \\
\text { heart will show us the right way. } \\
\text { 2. Our lives depend on the choices we make. }\end{array}$ \\
\hline $\begin{array}{l}\text { 3. Chris- } \\
\text { tiana }\end{array}$ & $\begin{array}{l}\text { 1. Compassion (empathy). } \\
\text { 2. Helping those in need (self-sacrifice). } \\
\text { 3. Modesty - the unfeigned feeling of not } \\
\text { wanting things for yourself not because } \\
\text { you are not in need yourself but because } \\
\text { someone else is more needy. }\end{array}$ & $\begin{array}{l}\text { 1. No one can escape from their destiny; one } \\
\text { can only be truly happy if following their } \\
\text { own unique path. } \\
\text { 2. Everyone's way goes through doing good } \\
\text { deeds, which return in time. }\end{array}$ \\
\hline 4. Pamela & $\begin{array}{l}\text { 1. Family values: solicitude and love } \\
\text { 2. Empathy. } \\
\text { 3. Showing respect and concern. } \\
\text { 4. Kindness / Humanity. } \\
\text { Anti-values: } \\
\text { - venality; } \\
\text { - acting under false pretenses; } \\
\text { - hypocrisy; } \\
\text { - hate; } \\
\text { - indifference. }\end{array}$ & $\begin{array}{l}\text { 1. Be generous to the have-nots. } \\
\text { 2. We should try not to be enticed by the easy } \\
\text { way to achieve something because eventually } \\
\text { the easy way always proves to be the more } \\
\text { difficult one. }\end{array}$ \\
\hline 5. Ana & $\begin{array}{l}\text { 1. Mutual understanding, love and respect in } \\
\text { the mother-son relationship. } \\
\text { 2. Kindness. } \\
\text { 3. Tenderness. } \\
\text { 4. Cordiality. }\end{array}$ & $\begin{array}{l}\text { 1. Be kind, compassionate, sympathetic and } \\
\text { generous to our relatives, to people in need } \\
\text { and to animals. } \\
\text { 2. We can be truly happy and content if we } \\
\text { try to contribute to the happiness and well- } \\
\text { being of other people. } \\
\text { 3. Family background and social class are not } \\
\text { important for being successful in life; rather, } \\
\text { success depends on personal qualities and } \\
\text { on the ability to overcome obstacles and dif- } \\
\text { ficulties. } \\
\text { 4. One cannot escape one's fate. }\end{array}$ \\
\hline
\end{tabular}




\begin{tabular}{|c|c|c|}
\hline & Values & Message \\
\hline 6. Radostina & $\begin{array}{l}\text { 1. All the gold in the world cannot replace the } \\
\text { boy's joy of his mother's recuperation. } \\
\text { 2. Persistence and purposefulness. } \\
\text { 3. Christian values: love, faith, hope, compas- } \\
\text { sion, kindness and charity. }\end{array}$ & $\begin{array}{l}\text { The young man is not tempted by gold. He is } \\
\text { focused and persistent - he doesn't stop even } \\
\text { for a moment; he does not lose determination, } \\
\text { even though he is very tired at the end of the } \\
\text { story. }\end{array}$ \\
\hline 7. Dilyana & $\begin{array}{l}\text { 1. Kindness. } \\
\text { 2. Purity of heart. } \\
\text { 3. Self-sacrifice in the name of those in need. } \\
\text { 4. What is of utmost importance for the boy } \\
\text { is not money and wealth but his mother's } \\
\text { health and well-being. } \\
\text { 5. Being strong-willed and determined; not to } \\
\text { waver despite the difficulties one can face. }\end{array}$ & $\begin{array}{l}\text { 1. When you do good - you get good. } \\
\text { 2. The importance of our relatives' health. } \\
\text { 3. Do not be selfish. } \\
\text { 4. It's important to be strong-willed and never } \\
\text { lose determination. } \\
\text { 4. One cannot escape from one's fate. } \\
\text { 5. We should be grateful for what we have and } \\
\text { be able to appreciate the things that really } \\
\text { matter in life. }\end{array}$ \\
\hline
\end{tabular}

Despite some variation in the responses, we can infer from the results that our readers have come to very similar conclusions and evaluations as to the expressed values and messages of the fairy tale. We can summarize that the basic axiological components of the fairy tale are kindness (5/7 answers), empathy / sympathy ( $5 / 7$ answers), building a strong bond in the family and love between mother and son (5/7) - the parent-child relationship, happiness, and the health of relatives are more important than material possessions, gold and money. Qualities such as modesty, humanity, warmth, determination and tenacity are also recognized as important values expressed in the text. A few answers emphasize the importance of Christian virtues, such as: faith, hope and love (love your neighbor, sacrifice in the name of the needy, willingness to help others). Most of the students find that happiness and success in life are achieved through being of service to others rather than through succumbing to one's personal desires and interest. One of the students reads in the hero's actions strong will that does not allow him to waver despite the difficulties he faces. One of the answers also mentions some anti-values seen as direct opposites to the positive qualities that the text affirms: mercantilism, hypocrisy, acting under false pretenses, hatred, indifference.

Looking at the messages expressed in the text, the student readers generally come to the conclusion that the main character becomes a happy person due to his positive qualities and his value system. Most of the answers emphasize the role that fate plays in one's life: One cannot escape from fate; no one can escape their destiny; people can be truly happy if they walk along their path, provided they do not deviate under the influence of temptations and they listen to their inner voice (their heart). At the same time, the opposite view is 
also expressed: the life of a person depends on the choice he or she makes; social origin is not a factor for success in life because personal qualities, determination and the ability of a person to overcome difficulties and obstacles are seen as the forces behind it ( $4 / 7$ answers). Additional messages that are mentioned focus on the readiness and joy to help people in need (4/7 answers). There is also the message that we should be grateful for what we have and that we should appreciate the things that really matter in life as well as the people we share our life with (2/7 views).

\section{ANALYTICAL TOOLS FOR DEVELOPING A LINGUISTIC MODEL INTERPRE- TING THE RESULTS}

During the analysis stage it became clear that most of the students use the plot of the tale and the ideas of travel and overcoming difficulties and obstacles in order to justify the messages and values they have identified in the text. As mentioned previously, the role of fate and luck as determinants of man's life and self-realization are also widely discussed in the answers. In some responses, the opinion that we cannot escape from our fate is expressed while others advocate the opposite idea - we are responsible for our own lives and the actions we take and the choices we make determine who we are.

This gives us reason to construct an analytical apparatus describing how readers reach the ethical and moral values that are implicitly expressed in the story. We use a methodological framework developed by Lakoff \& Johnson (1980) and Lakoff \& Turner (1989), using the conceptual metaphor theory within the framework of cognitive linguistics. We add to it cultural models, typical of the Bulgarian linguaculture and linguistic worldview. Our choice is based on the following reasons:

1. There is a great degree of overlap between the plot of the fairy tale and the structure of the conceptual metaphor Life is a journey. In fact, the metaphor infuses the whole text, thus becoming a vital part of the narrative itself, a part which cannot possibly be ignored at interpretation level.

2. Lakoff and Turner convincingly reveal the role of conceptual metaphors in understanding and constructing the meaning of literary works by readers:

... people have, as part of their normal conceptual systems, a wealth of conceptual metaphors that they use to make sense of their experience. Many meanings are conventional and shared, and these limit what a literary work can mean to someone. Literary works, for this reason, can't mean just anything. (Lakoff \& Turner 1989: 109-110) 
As we are more interested here in the cognitive aspect of the matter, the conceptual theory framework can help us to try to understand how, in this particular text... we think in narrative and how exactly it is that narrative helps us think (Popova 2015:10).

3. The text is rich in images and notions typical of the Bulgarian linguistic and cultural worldview (bread, luck, fate); therefore they are also considered as factors influencing meaning construal.

\section{ON CONCEPTUAL METAPHORS}

According to Lakoff \& Johnson (1980) and Lakoff \& Turner (1989), in every language there is a set of basic metaphorical concepts that are at the heart of conceptualizing and understanding our world and forming our worldview. They convincingly prove that the conceptual system of people is structured metaphorically and certain aspects of our lives are represented metaphorically in a systematic way. In their view, metaphor is not so much a figure of speech but a basic tool employed in understanding and shaping our experience: Far from being merely a matter of words, metaphor is a matter of thought - all kinds of thought: thought about emotion, about society, about human character, about language, and about the nature of life and death. (Lakoff \& Turner 1989: xi).

According to them, conceptual metaphors have the following main features:

- They are part of the common conceptual apparatus of the members of a given culture and are mutually understandable due to common shared experiences.

- They are systematic, i.e. there is an established correspondence between the source domain structure and the target domain.

- For most of them, their use is automatic and habitual, although the possibility of special emphasis on them is not excluded.

- They are highly conventionalized in the language, i.e. there is a large number of lexemes and idiomatic expressions whose interpretation depends on these metaphors.

- They create a structure in our understanding of life, and also help to construe the meaning of the literary works.

\section{ON THE CONCEPTUAL METAPHOR LIFE IS A JOURNEY}

One of the main conceptual metaphors that Lakoff and Turner exploit in their guide to poetic metaphor is Life is a journey whose structure is reflected in the mapping of two conceptual domains - travel (source domain) and life (target domain). They list the following elements of the metaphor: 
(i) The person leading a life is a traveler;

(ii) His purposes are destinations;

(iii) The means for achieving purposes are routes;

(iv) Difficulties in life are impediments to travel;

(v) Counselors are guides;

(vi) Progress is the distance traveled;

(vii) Things you gauge your progress by are landmarks;

(viii) Choices in life are crossroads;

(ix) Material resources and talents are provisions (Lakoff \& Turner 1989: 3-4).

It is obvious how this structure corresponds to the storyline of Medenata Pita. The metaphor is not merely at word or sentence level; rather it permeates the whole text. Table 2 lists the main elements of the correlation between the metaphor and the plot of the story.

\section{Table 2}

\begin{tabular}{|c|c|}
\hline Source: Journey & Target: Correspondence with the Fairy Tale Text \\
\hline The travelers & The young boy sets off to seek his fortune. \\
\hline The vehicle & $\begin{array}{l}\text { The boy walks along following his fate (the honey bread that was rolled ahead at his } \\
\text { birth) - a representation of life. }\end{array}$ \\
\hline The journey & $\begin{array}{l}\text { The boy reaches the end of the world and gets back to his mother thus the journey } \\
\text { represents the different events in his life. }\end{array}$ \\
\hline The distance covered & $\begin{array}{l}\text { This is the idea of the age of a person: at the beginning of the tale the protagonist is a } \\
\text { young boy but when he finds the rolled honey bread he is already a mature man. }\end{array}$ \\
\hline Obstacles encountered & $\begin{array}{l}\text { Obstacles and difficulties encountered along the way - The boy crossed meadows and } \\
\text { mountains, his legs got sore and injured... }\end{array}$ \\
\hline $\begin{array}{l}\text { Decisions about where } \\
\text { to go }\end{array}$ & $\begin{array}{l}\text { The choices the protagonist makes in order to distinguish between good and bad; he } \\
\text { chooses the simple rye bread instead of choosing the Golden Land. }\end{array}$ \\
\hline The destination & $\begin{array}{l}\text { In Konstantinov's tale the narrative ends where it began - the boy's home - thus em- } \\
\text { phasizing the idea of a fulfilling life and a sense of life purposes and goals that have } \\
\text { been achieved. }\end{array}$ \\
\hline
\end{tabular}


Life is a journey as a conceptual metaphor is common for many Indo-European languages; it is also significant for the Bulgarian linguaculture. The Bulgarian language is rich in expressions that show how we think of a complex concept such as life through the idea of travel: we come to this world and leave it for good; we say that we are at a crossroads when we have to make a difficult choice or we reach our goals, etc.

It could be assumed that the metaphor defines the framework within which the interpretation of the members of the Bulgarian linguaculture occurs. As Popova points out: metaphor, when used in narrative on the word, sentence and even text level, serves the purposes of the narrative itself (Popova 2015: 66). This is how the tale can be interpreted as an allegory, i.e. the story is about something else than what is narrated on the surface. So, implicitly, the tale becomes not a story about the individual journey of the main character but suggests the idea of a life well-lived and the ultimate path of salvation of every man. The journey the protagonist undertakes leads to his personal self-realization and even though at the end of the story neither his social nor material status has changed, he has achieved something even more valuable - a golden heart seen as a symbol of all that matters in life - beauty of soul. This idea is something that our readers identified as being part of the message level of the fairy tale: the belief that it is possible to overcome all obstacles in life, that everyone has a good destiny, that good always prevails, and even the ordinary poor man can finally find his or her true nature. Or, as Flahault writes, the character reaches [...] the nucleus of their own personality, which contains the seeds of their personal self- realization, a power of life that is enshrined in its entirety, even if the external conditions are hostile, and even if no other character comes to the hero's help (Flahault 2002: 12).

However, in the development of the plot, we observe the opposition between fate and human choice. At the text level, the concepts of fortune tellers, fate and destiny are found in the exposition of Konstantinov's tale at the point of the rising action:

- When you were born, my son, a fortune teller rolled a loaf of honey bread, and said, "This is his luck. Let him chase it around the world. When he reaches his fortune, he'll be happy." But it was hard for me to let you go. I did not say anything to you, and now the fortune teller is punishing me. I will die unless you find the honey bread and bring it back together with my and your happiness. Go, son, wander the world and chase your luck! (Konstantinov 1972: 35)

These opposing notions are also reflected in the students' answers: some students believe that a main message lies in the idea of irrevocability of fate and values such as following one's destiny to the best possible end are to be inferred from the text. Others, on the 
other hand, believe that it is the individual choices made along the life journey that ultimately lead to achieving one's life purposes and goals.

Thus, the idea of destiny or fate, an important element of Bulgarian linguaculture, proves to be an important part of the Bulgarian concept of Life is a journey that guides interpretation. If we look deeper into it, we find out that it has a significant presence in the different forms of folk art and it is believed that it is determined at the birth of a person. In Bulgarian folk concepts and perceptions, the life of a child is predetermined by fortune tellers who tell the fate of the newborn on the third night after the birth. In his study Mythic Songs. Origin and Basic Motives published in Essays on Bulgarian Folklore, Mihail Arnaudov claims that the Bulgarians take the idea of the fortune tellers from the Greek (from

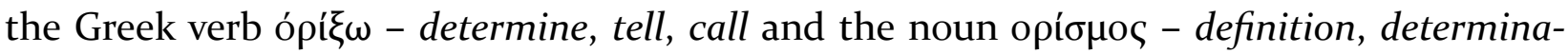
tion). The author points out the connection with the ancient idea of the goddesses of fate. Arnaudov recalls Hesiod, according to whom the goddesses, daughters of Zeus, are three: one of them spins the thread of life, the second determines its length, and the third, the irrevocable one, cuts it (Arnaudov 1996: 614). This number is significant in Bulgarian folk beliefs, as well. The idea of the irrevocability of fate is preserved in many Bulgarian proverbs and sayings: Тъй му било писано и наречено (This is what was foretold to be his / her fate); Тъй го орисали орисниците (This is what the fortune tellers fortold to be his / her fate) (Minkov 1963); Такава му е орисията (This is what his / her fate is); Що е на глава писано, на камък не иде (lit. What has been written on the head, does not go on stone, meaning One cannot escape from his / her fate) (Georgieva 1983: 138), to cite but a few. Ivanitchka Georgieva points out that mythical beings similar to the Bulgarian fortune tellers (орисници) are commonly believed to exist in other nations as well (Serbs, Croats, Slovenians, Czechs, Russians, as well as the German, Baltic, Caucasian and Siberian peoples) (Georgieva 1983: 141). Mihail Arnaudov writes that the belief in the fortune tellers and in one's luck is part of Bulgarian demonology, but it is clear from the cited examples that they are related to a wider Balkan or even European linguistic picture of the world.

Therefore, at a conceptual level, for a Bulgarian reader it could be either the idea of following one's destiny or the notion of choices made along the way that guides a person through their life journey and can lead to one's self-fulfillment. Or it could be a mixture of the two - we have to do what is predestined but if we are able to choose wisely along the way, then self-fulfillment is achievable at a satisfactory level. The interpretation seems to depend on the personal schemas a reader brings along during the process of reading and meaning construal. The distance travelled (the length of one's life) and life difficulties one has to overcome are important elements of the story meaning underlined by fact that as long 
as a person sticks to important values such as kindness, empathy, love or determination and tenacity, the end will always be satisfactory and rewarding. As Lakoff and Turner reason:

\begin{abstract}
All reading involves construal... For any given person, some construals will seem more natural than others, and those are the ones that are often ascribed to the intention of the poet. But if we actually talk to contemporary poets about their poems, we find that the poet's most natural construals may not be our own. That is normal, inevitable, and part of what akes poetry valuable and of lasting interest. (Lakoff \& Turner 1989: 109-110)
\end{abstract}

\title{
SPECIFIC CULTURAL IMAGES AND MEANINGS
}

In addition, the text of the fairytale is rich in images and meanings related to specific cultural models typical of the Bulgarian linguo-cultural worldview: bread, fortune tellers, luck.

Bread is a key image of the Bulgarian cultural picture of the world. In Bulgarian folk culture, bread is a sacred symbol which has a significant role in the ritual system and is linked both to the life cycle (birth - wedding - death) and to the events of the traditional calendar: Ritual bread bears the idea of birth, death and the new birth. The ground flour and the baked bread are seen as a kind of transformation of the movement from nature to culture, that is, from the world of nature to the human world (Avginova-Nikolova 2017: 417). Yaneva adds that bread becomes a fact of the Bulgarian spiritual culture when it is associated with the ritual system (Yaneva 1989: 9). Dacheva summarizes the rituals related to bread and childbirth:

... immediately after birth, the so called fast bread is made, on the third day a second loaf is prepared and it is consumed only by women (for health, happiness and fertility). (Dacheva 2000: 149)

It is believed that on the third or even the same night after the birth of a child the fortune tellers come - three sisters in white clothes, they stand near the hearth or the chimney and start to spur the thread of life of the newborn and they do so until the first rooster crow is heard, and so they start to tell the fortune [...] To be predisposed, they are welcomed with a meal specifically set for them and a specially prepared ritual bread has a central place on the table. (Dacheva 2000: 149)

Ritual loaves of bread are prepared for the christening of children, as well as when they start to walk; a good example is the traditional Bulgarian ritual called proshtapulnik which involves a toddler going after a round loaf of bread that has been rolled ahead; this is done to determine the child's future profession or craft. There is a great deal of similarity between this ritual and the text of the analyzed tale. In fact, the rolled bread can be seen as a metaphor of human life. 
In addition to the rich ritual use of bread, in Bulgarian there are a great number of proverbs and sayings around the lexeme bread which comes to intensify the importance of bread in Bulgarian culture. In the Bulgarian language there are expressions like: Изкарвам си хляба (Earn one’s bread); Никой не е по-голям от хляба (No one is bigger than bread); Хлябът е по-голям и от царот (Bread is bigger than the king); Половин хляб - половин късмет (Half bread - half luck); Къща без хляб да не замръква (A household shouldn't be left without any bread at the end of the day). There is even an oath: Да те убие хлябът! (May bread kill you!) (Zaykov \& Raychevski 1984: 11).

The type of bread is also important. Avginova-Nikolova (2017) points out that sweet bread (with honey) is served at rituals such as birth, or when a child starts to walk independently, i.e. initiation rituals. Honey is considered to be a blessed gift of nature, an elixir of life and a symbol of immortality - a notion typical of all ancient mythological systems tied to the different stages of human civilization (Stoynev 2006: 193). In addition, wheat bread, i.e. bread made of good flour brings positive connotations for the Bulgarians, while brown bread is associated with poverty and misery (Cf. Омръзна ми да бъда черен хляб (I am tired offeeling like brown bread). = I am tired of feeling poor or deprived).

Thus, the metamorphosis of the bread in the fairy tale - from a loaf made with honey to a hard loaf made of the darkest kind offlour - a cracked, rough loaf of bread - becomes a symbol of the hero's initiation and growth. The main character manages to resist the temptations offered to him along the way, thus revealing strong character and determination in following his goals, ideas which are identified as important values in the text. The interviewed students are holders of the Bulgarian linguistic culture so they naturally use the established cultural models for the role that bread plays in it in order to reach their conclusions.

Another idea presented in the tale is the notion of good luck. Mihail Arnaudov believes that the word luck (късмет) is a loanword from Turkish, who in turn loaned it from West Asian peoples (Arnaudov 1996: 67). In Turkish it means good chance, honor, a good meeting. The Bulgarians take up the idea of luck, which is reflected in many proverbs: Късметя ù om педя (She is fortunate from when she was a small child); Роди ме с късмет и фърли ма на купище (One's good luck is obvious even in the hardest of circumstances); Човек с късметя cu ce paжda (A man is born with his luck), etc.

In Konstantinov's story, for the creatures in the Golden Land, there is no better luck than the possession of gold. In their world everything is of pure gold - the trees, the fruits, the jewelry. But the author indirectly gives his assessment of the creatures living in the Golden Land: they are strange people, resembling big lizards and frogs. Lizards and frogs have a pronounced chthonic character and are associated with a deeply negative value model. Thus, two value models are opposed and the imaginary worlds narrated in the tale 
play a vital role in the artistic representation of this opposition. For the people of the Golden Land, for example, the material possessions and the prosperity expressed in gold are of primary importance. For the boy, on the other hand, it is essential to fulfill his mother's request and find the honey bread. But when this is done, the boy does not leave it for himself, but distributes it to the needy.

The ending of the tale is especially significant in this respect; this is the episode when the mother addresses her grown-up son:

- No, my son, you are not going to die. On the contrary, now you are going to live happy and content. You did all that the fortune teller had foretold. So here I am now, healthy and healed and you will always be with me. But all you went through had to happen. You had to go and see the world with all the good and bad in it and you had to choose between the two. You had to find the honey bread and give it to the needy and not to act out of self-interest. Don't be sorry about the bread loaf, my son! I don't need it any more. You brought me your golden heart, didn't you! Not take that loaf of rye bread from the shelf over there, come and sit and let us dine together. And you will see that it will be more delicious than all the honey bread in the world! (Konstantinov 1972: 37-38)

The metaphor of the golden heart links etiologically with beauty and kindness of soul. Self-realization is achieved by living for the others and ignoring self-interest and personal needs.

\section{CONCLUSION}

The value-axiological approach to the study of literary works is of great importance for the aesthetic world perception and a necessary condition towards the building of a value system. Julia Doncheva points out:

Moral norms and requirements are based on public opinion, beliefs, traditions and habits. They are mandatory components in the structure of a moral system. There are also components for the coordination of moral requirements and views. These are moral knowledge, beliefs, and related moral motives for behavior, moral judgment, and self-esteem. The criterion for moral assessments is the public interest expressed in the shared public opinions for good and bad. (Doncheva 2014: 28)

Therefore, we believe that the focus on the axiological elements of language is essential in the education and preparation of future teachers.

In this paper, we tried to build a complex methodological apparatus for studying readers' perceptions regarding the axiological aspects of a text. Starting from a survey with undergraduate students, we built an analytical linguistic model. The conceptual metaphor Life is a journey created by Lakoff and Johnson (1980) and Lakoff and Turner (1989) served 
as a theoretical underpinning; we compared its structure to the plot of the tale Medenata Pita. We enriched the model with the interpretation of words and images typical of the traditional Bulgarian culture (bread, destiny / fate, fortune tellers, luck) and tried to explore the connection between the students' answers, the linguo-cultural analytical apparatus and Konstantin Konstantinov's text.

We have reason to believe that this complex model can be used successfully to explain the axiological meanings that readers infer from an expanded text. In other words, it allows the explication of the evaluative meaning from the viewpoint of the reader which is important from a linguo-cultural point of view, because it makes possible the study of the linguistic picture through the prism of a certain linguo-cultural personality.

\section{REFERENCES}

Arnaudov 1996: Arnaudov, Mihail. Essays on Bulgarian Folklore. Vol. 2. Sofia: Prof. Marin Drinov Academic Press, 1996. [In Bulgarian: Арнаудов, Михаил. Очерци по българския фолклор. Т. 2. София: АИ Проф. Марин Дринов, 1996.]

$\therefore \quad$ Avginova-Nikolova 2017: Avginova-Nikolova, Emilya. "The place of bread in the Bulgarian and Greek culture." In Proceedings from the Arnaudov Readings Conference. Vol. 9, 416-422. Ruse: Leni An, 2017. [In Bulgarian: Авгинова-Николова, Емилия. “Мястото на хляба в културата на българите и гърците.” B: Арнаудов сборник. Т. 9, 416-422. Русе: Лени Ан, 2017.]

Booth 1983: Booth, Wayne C. The Rhetoric of Fiction. Second edition. Chicago: The University of Chicago Press, 1983.

Dacheva 20oo: Dacheva, Svezha. On the Good Girl and the Bad Girl. Sofia: Sineva, 200o. [In Bulgarian: Дачева, Свежа. За доброто и за лошото момиче. София: Синева, 20оо.]

Doncheva 2014: Doncheva, Julia. Consolidating Functions of Bulgarian Folk Games Used at Pre-School Age. Ruse University Press, 2014. [In Bulgarian: Дончева, Юлия. Консолидиращите функциии на българските детски фолклорни игри в предучилищна възраст. Русе: УИ на Русенски университет, 2014.]

Dushkova 2012: Dushkova, Mira. Semper Idem: Konstantin Konstantinov. Poetics of Konstantinov's Late Stories. Ruse: Leni An, 2012. [In Bulgarian: Душкова, Мира. Semper Idem: Константин Константинов. Поетика на късните разкази. Русе: Лени Ан, 2012.]

Flahault 2002: Flahault, Francois. "Self-realization in Fairy Tales." Bulgarian Folklore, No 3-4 (2002), 11-15. [In Bulgarian: Флао, Франсоа. “Себеосъществяването в приказките.” Български фолкор, № 3-4 (2002), 11-15.]

Georgieva 1983: Georgieva, Ivanichka. Bulgarian Folk Mythology. Sofia: Nauka i Izkustvo, 1983. [In Bulgarian: Георгиева, Иваничка. Българска народна митология. София: Наука и изкуство, 1983.] 
Gospodinova 2003: Gospodinova, Krassimira, ed. My Book on Konstantin Konstantinov. Sliven: Shturche, 2003. [In Bulgarian: Господинова, Красимира, ред. Моята книжка за Константин Константинов. Сливен: Щурче, 2003].

Konstantinov 1972: Konstantinov, Konstantin. Fairy Tales for You. Selected Fairy Tales and Stories. Sofia: Narodna Mladezh, 1972. [In Bulgarian: Константинов, Константин. Приказки за тебе. Избрани приказки и разкази. София: Народна младеж, 1972.]

Lakoff \& Johnson 1980: Lakoff, George \& Mark Johnson. Metaphors We Live By. Chicago: The University of Chicago Press, 1980.

Lakoff \& Turner 1989: Lakoff, George \& Mark Turner. More Than a Cool Reason. A Field Guide to Poetic Metaphor. Chicago: University of Chicago Press, 1989.

Minkov 1963: Minkov, Tsvetan, ed. Bulgarian Folk Art. Vol. 12. Proverbs, Sayings, Riddles. Sofia: Balgarski pisatel, 1963. [In Bulgarian: Минков, Цветан, съст. и ред. Българско народно творчество. Т. 12. Пословици, поговорки, гатанки. София: Български писател, 1963.]

Phelan 2007: Phelan, James. "Rhetoric / Ethics." In Herman, D., ed. The Cambridge Companion to Narrative, 203-216. Cambridge University Press, 2007.

Popova 2015: Popova, Yanna. Stories, Meaning, and Experience. Narrativity and Enaction. New York: Routledge, 2015.

Stoynev 20o6: Stoynev, Anani, ed. Bulgarian mythology. Encyclopedic Dictionary. Second Completed Edition. Sofia: Zahari Stoyanov, 20o6. [In Bulgarian: Стойнев, Анани, съст. Българска митология. Енциклопедичен речник. Второ допълнено издание. София: Захари Стоянов, 20о6].

Yaneva 1989: Yaneva, Stanka. Bulgarian ritual breads. Sofia: BAN, 1989. [In Bulgarian: Янева, Станка. Български обредни хлябове. София: БАН, 1989].

Zaykov \& Raychevski 1984: Zaykov, Iliya \& Stoyan Raychevski. Book of Bread. Plovdiv: Hristo G. Danov, 1984. [In Bulgarian: Зайков, Илия \& Стоян Райчевски. Книга за хляба. Пловдив: Христо Г. Данов, 1984.] 